\title{
PENINGKATAN KETERAMPILAN SISWA SMA/MA BIDANG SAINS DAN TEKNOLOGI MELALUI PELATIHAN ROBOTIKA BERBASIS MIKROKONTROLLER
}

\author{
Hozairi \\ Prodi Teknik Informatika, Fakultas Teknik, Universitas Islam Madura, dr.hozairi@gmail.com
}

Akhmad Arif Kurdianto

Prodi Teknik Listrik Industri, Politeknik Negeri Madura

\begin{abstract}
Abstrak
Sekolah Menengah Atas / Madrasah Aliyah (SMA/MA) adalah satuan pendidikan formal yang menyelenggarakan pendidikan formal ditingkat menengah. Permasalahan yang dialami oleh SMA/MA di Kabupaten Pamekasan adalah masih ada $\pm 25 \%$ lulusan dari SMA/MA yang tidak melanjutkan studi, sehingga mereka menjadi tenaga yang kurang produktif karena tidak memiliki keterampilan. Untuk membantu menyelesaikan permasalahan tersebut maka perlu dirancang dan disusun model pelatihan yang efektif dan efisien yang mampu membantu lulusan SMA/MA lebih terampil dibidang sains dan teknologi. Berdasarkan analisa potensi wilayah Pamekasan dan perkembangan dunia usaha \& industri maka pelatihan yang cocok untuk dikembangkan di Kabupaten Pamekasan adalah pelatihan robotika. Tahapan pelaksanaan pelatihan tersebut dimulai dari (1) proses pendaftaran peserta, (2) proses pemilihan peserta, (3) pre test, (4) pelaksanaan pelatihan robotika (perakitan dan pemprograman), (5) post test dan (6) evaluasi hasil. Hasil analisa pelaksanaan pelatihan selama dua hari diperoleh respon peserta yang bervariasi, yaitu: cukup $=13 \%$, baik $=49 \%$ dan sangat baik $=38 \%$. Hasil ini menunjukkan bahwa pelatihan keterampilan robotika telah memberikan outcome yang sangat baik bagi peningkatan kemampuan dan keterampilan siswa SMA/MA di Kabupaten Pamekasan.
\end{abstract}

Kata Kunci: pelatihan, keterampilan, robotika, SMA/MA

\section{Abstract}

Senior High School or Madrasah Aliyah (SMA / MA) is a formal education unit that organizes formal education at the secondary level within the Education and Ministry of Religion. The problems experienced by SMA / MA in Pamekasan Regency are that there are still around 25\% of graduates from SMA / MA who do not continue their studies, so they become less productive because they do not have skills. To help resolve these problems it is necessary to design and compile an effective and efficient training model that is able to help high school / MA graduates more skilled, especially in the fields of science and technology. Based on the analysis of the potential of the Pamekasan region and the development of the business \& industry, the appropriate training to be developed in Pamekasan Regency is training in robotics. The stages of the training start from (1) the participant registration process, (2) the process of selecting participants, (3) pre test, (4) the implementation of robotics training (assembly and programming), (5) post test and (6) evaluation of results. The results of the analysis of the implementation of the two-day training obtained varied participants' responses, namely: enough $=13 \%$, good $=49 \%$ and very good $=38 \%$. These results indicate that robotics skills training has provided very good outcomes for improving the abilities and skills of high school / MA students in Pamekasan Regency.

Keywords: training, skills, robotics, SMA/MA

\section{PENDAHULUAN}

Kemajuan ilmu pengetahuan dan teknologi telah mempengaruhi kehidupan sosial masyarakat baik dalam dunia pendidikan, dunia kerja dan sosial budaya menuju arah global. Dampak positif dan negatif yang timbul didalam masyarakat global adalah tantangan berkaitan dengan kompetensi yang berdimensi global (Erni Setiyorini, Ning Arti Wulandari, 2018). Untuk menghadapi tantangan tersebut maka solusi yang harus disiapkan adalah 
menyiapkan Sumber Daya Manusia (SDM) yang berkualitas yang berwawasan unggul dan berdaya saing tinggi (Gardening \& Activity, 2017). Masalah selanjutnya adalah bagaimana meningkatkan kualitas Sumber Daya Manusia (SDM) yang berkualitas yaitu dengan penguatan penguasaan teknologi dan sains.

Sekolah Menengah Atas (SMA) atau yang sederajat yaitu Madrasah Aliyah (MA) di Kabupaten Pamekasan berjumlah 188 sekolah yang tersebar di 13 kecamatan Kabupaten Pamekasan. SMA/MA bertujuan diantara menyediakan dan menyiapkan siswa - siswi yang ingin melanjutkan studi ke jenjang yang lebih tinggi, Akademi atau Perguruan Tinggi (Noor, 2015), (Mirza \& Indah, 2015), (Adriyani, 2017).

Permasalahan lulusan SMA/MA di Kabupaten Pamekasan adalah masih ada sekitar 25\% lulusan yang tidak melanjutkan studi artinya mereka ingin bekerja atau membuka usaha (Gardening \& Activity, 2017), (Masruroh, 2017). Bagaimana menyiapkan siswa/siswi yang tidak melanjutkan tersebut memiliki keterampilan yang bisa digunakan untuk mencari kerja atau membuka usaha, yaitu dengan memberikan keterampilan bidang teknologi informasi dan elektronika.

Untuk membantu Pemerintah mengatasi permasalahan tersebut Fakultas Teknik Universitas Islam Madura (FT UIM) bekerjasama dengan Program Studi Teknik
Listrik Industri (TLI) Politeknik Negeri Madura melaksanakan program pengabdian kepada masyarakat untuk memberikan pelatihan dan pendampingan bidang elektronika khususnya membuat robot berbasis mikrokontroller.

Program pengabdian masyarakat ini dilakukan dengan target peserta adalah perwakilan siswa SMA/MA di Kabupaten Pamekasan. Peserta dibatasi maksimum 30 dengan perwakilan masing-masing sekolah 2 siswa. Target capaian dari program pengabdian masyarakat ini adalah setiap peserta mampu merakit robot dan mampu membuat program aplikasi untuk otak robot supaya robotnya bisa secara otomatis mampu berfikir seperti manusia (Wijaya, Bisnis, Manajemen, Petra, \& Siwalankerto, 2013), (Mirza \& Indah, 2015), (Anitasari, Bisnis, Manajemen, Petra, \& Siwalankerto, 2017), (Adriyani, 2017), (Asri, 2018).

GAMBARAN UMUM MASYARAKAT SASARAN

Kabupaten Pamekasan memiliki 13 Kecamatan di Kabupaten Pamekasan, dengan jumlah total SMA Negeri $=9$ dan SMA Swasta $=69$. Untuk MA Negeri $=2$ dan MA Swasta $=108$ sekolah yang tersebar dibeberapa Kecamatan. Untuk sebaran data SMA dan MA dapat terlihat pada Tabel 1. 
Tabel 1. Jumlah SMA/MA di Pamekasan

\section{SMA/MA di Pamekasan Jumlah}

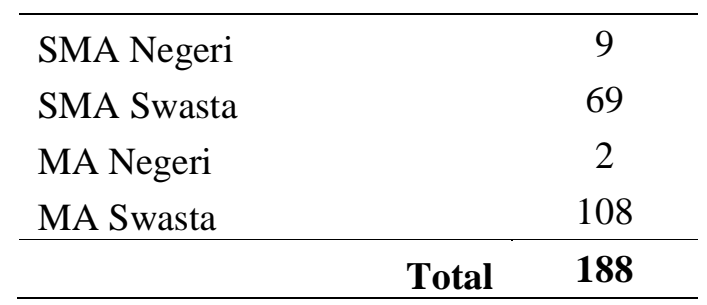

Peserta yang mengikuti program pelatihan robotika adalah perwakilan dari 7 MA dan 8 SMA dengan total peserta 30 orang. Proses pemilihan peserta dilakukan melalui seleksi dengan mengisi form kesanggupan dan kesiapan untuk mengikuti pelatihan dari awal sampai akhir selama 14 Jam (2 Hari). Data peserta yang mengikuti acara pelatihan tersebut bisa dilihat pada Tabel 2.

Tabel 2. Jumlah peserta pelatihan Robotika

\begin{tabular}{clc}
\hline No & Nama Sekolah & $\begin{array}{c}\text { Jumlah } \\
\text { Peserta }\end{array}$ \\
\hline 1 & SMAN 1 Galis & 2 \\
2 & SMAN 1 Pademawu & 2 \\
3 & SMAN 1 Pakong & 2 \\
4 & SMAN 2 Pamekasan & 2 \\
5 & SMAN 4 Pamekasan & 2 \\
6 & SMAN 5 Pamekasan & 2 \\
7 & SMAN 1 Waru & 2 \\
8 & SMA Maarif & 2 \\
9 & MAN 1 Pamekasan & 2 \\
10 & MAN 2 Pamekasan & 2 \\
11 & MA Mambaul Ulum & 2 \\
12 & MA Miftahul Ulum & 2 \\
13 & MA Darul Ulum & 2 \\
14 & MA Mabdaul Falah & 2 \\
15 & MA Bustanul Ulum & 2 \\
\hline \multicolumn{2}{c}{ Total Peserta } \\
\hline
\end{tabular}

Sebaran jumlah peserta yang mengikuti program pelatihan bidang sains dan teknologi terlihat pada table.2. Peserta yang dilatih adalah siswa SMA/MA yang sudah duduk pada kelas 11 dengan rekomendasi pihak sekolah, setiap peserta diwajibkan membawa peralatan dasar untuk elektronika (solder, penyedot timah, tang cucut dan avo meter). Harapan dan target dari program pengabdian masyarakat ini adalah menyiapkan SDM yang handal dan unggul dibidang teknologi informasi serta elektronika. Target kegiatan selama 2 hari tersebut difokuskan pada perakitan hardware robot dan hari kedua difokuskan pada penggunaan software.

\section{METODE}

Pelaksanaan program pengabdian kepada masyarakat ini dilakukan beberapa tahapan, yaitu: (1) Sosialisasi program pengabdian masyarakat kepada sekolah calon peserta; (2) Proses pendaftaran dan pengisian formulir secara online, bagi sekolah yang sudah bersedia mengikuti kegiatan dari awal sampai akhir; (3) Pelaksanaan Pelatihan selama 2 hari (hari pertama perakitan, hari kedua pemprograman); (4) Evaluasi dan traouble shooting. Secara detail tahapan pelaksanaan program pengabdian kepada masyarakat dapat dilihat pada Gambar 1.

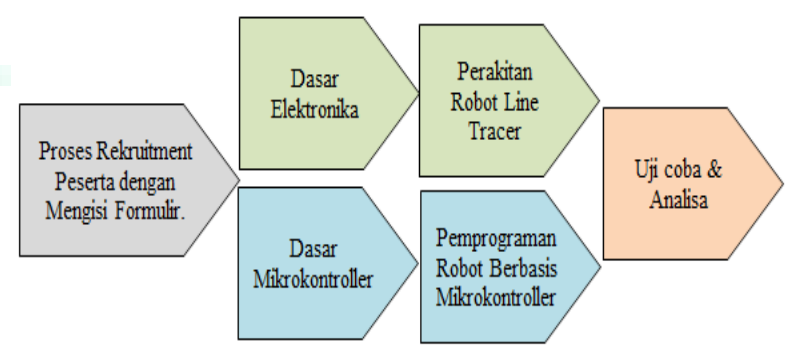

Gambar 1. Tahapan pelaksanaan pengabdian masyarakat 
Keterangan:

- Tahap 1: Proses sosialisasi program abmas

- Tahap 2: Proses pendaftaran

- Tahap 3: Proses pelatihan (perakitan \& pemprograman)

- Tahap 4: Uji coba dan analisa

Bahan yang disiapkan untuk kelancaran pelaksanaan program pengabdian kepada masyarakat tentang pembuatan robot line tracer berbasis mikrokontroller seperti terlihat pada Tabel 3.

Tabel 3. Komponen yang dibutuhkan

\begin{tabular}{cl}
\hline No & \multicolumn{1}{c}{ Nama Komponen } \\
\hline 1 & ATMEGA16A \\
2 & Soket 40p \\
3 & Motor Penggerek+mekanik \\
4 & Lipo Battery \\
5 & Motor DC gear \\
6 & Roda bebas \\
7 & Motor driver \\
8 & Acrilyc griper \\
9 & Soket Ampenol 10P female \\
10 & Resistor \\
11 & Capasitor \\
12 & IC Regulator \\
13 & Sensor+LED \\
14 & Soket lipo batt male \\
15 & Push button \\
16 & On/OFF switch \\
17 & PCB double layer \\
18 & LCD 16x2 white \\
19 & White house 2P male \\
20 & White house 2P female \\
21 & White house 8P male \\
22 & White house 8P female \\
23 & Kabel Tunggal \\
24 & Baut+mur \\
25 & Spacer 6cm \\
26 & Pinhead 5P male \\
27 & Pinhead 5P female \\
28 & Limit swith \\
29 & Roda + karet ban \\
30 & Servo motor \\
\hline &
\end{tabular}

Untuk peralatan yang diberikan kepada peserta adalah 1 unit PCB double layer, 1 paket peralatan elektronika. Masing-masing peserta wajib bekerjasama untuk saling membantu menyelesaikan proses perakitan robot.

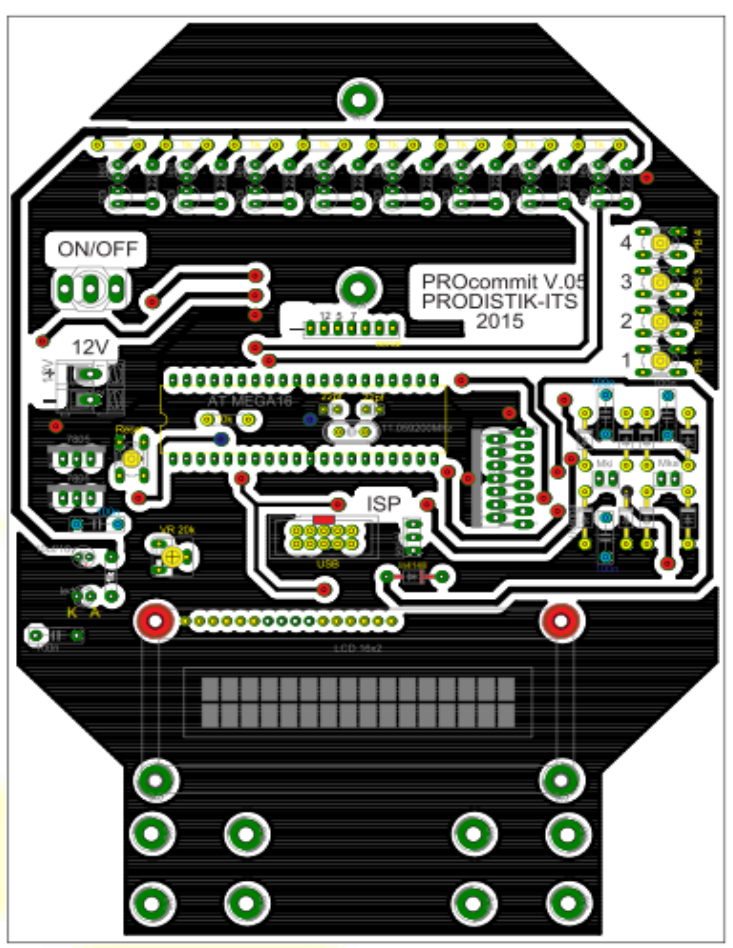

Gambar 2. PCB Robot terlihat riil dari atas

\section{Printed Circuit Board atau (PCB)} adalah sebuah papan yang penuh dengan sirkuit dari logam yang menghubungkan komponen elektronik yang berbeda jenis maupun sama satu sama lain tanpa kabel.

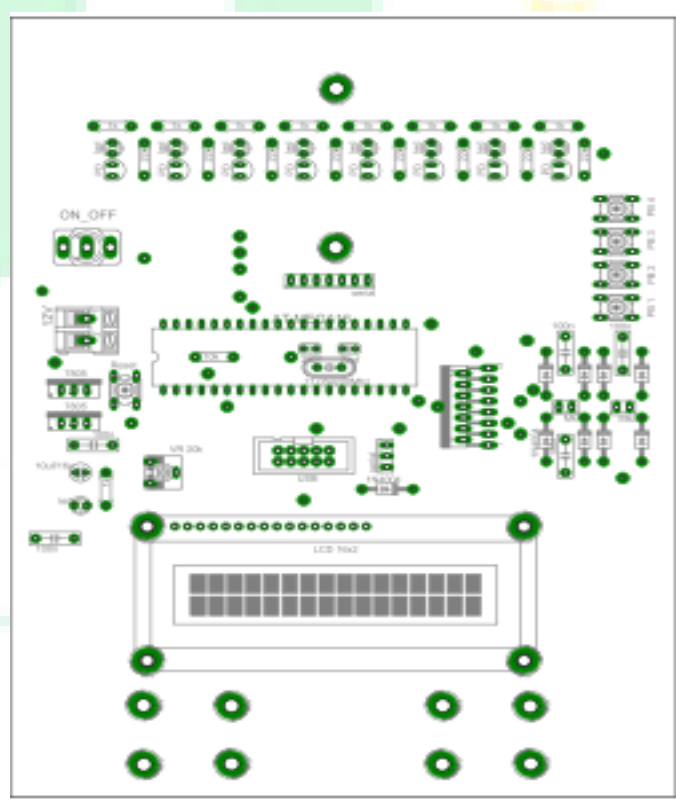

Gambar 3. PCB Robot terlihat dari atas

Desain PCB yang akan dirakit oleh peserta terlihat pada gambar 2 dan 3. Untuk gambar 2 terlihat tampak riil dari atas tempat penempatan 
komponen yang ada, sedangkan untuk gambar 3 terlihat tampak dari atas alur komponen yang sudah dipasang pada PCB.

\section{HASIL DAN PEMBAHASAN}

Hasil dari pelaksanaan program pengabdian kepada masyarakat antara Universitas Islam Madura dan Politeknik Negeri Madura telah menghasilkan beberapa luaran sebagai berikut:

1. Terbentuknya kerjasama antar institusi perguruan tinggi untuk membantu Pemerintah menyelesaikan permasalahan lulusan SMA/MA.

Program pengabdian masyarakat ini terlaksana atas kerjasama antara Universitas Islam Madura dan Politeknik Negeri Madura untuk bersama-sama membantu masyarakat (siswa) untuk mendapatkan keterampilan tambahan dibidang elektronika khususnya perancangan robot cerdas berbasis multikontroller.

2. Terlaksananya program pelatihan selama 2 hari (14 Jam) dibidang elektronika khususnya robotika.

Pelatihan robotika ini dilaksanakan selama 2 hari atau setara dengan 14 jam, pelaksanaan ini dilaksanakan pada hari sabtu dan minggu sehingga tidak mengganggu pelajaran siswa SMA/MA.

\section{Terbentuknya sinergi antara Perguruan Tinggi dengan Sekolah yang ingin membekali lulusanya keterampilan elektronika.}

Program pengabdian masyarakat yang telah dilaksanakan memberikan dampak yang bagus bagi mitra, yaitu terbangunnya sebuah sinergi antara perguruan tinggi dengan SMA/MA. Pihak SMA/MA mitra yang telah dibina oleh kedua perguruan tinggi tersebut akan memperoleh akses masuk perguruan tinggi melalui jalur undangan sesuai dengan syarat-syarat yang ditetapkan oleh masing-masing perguruan tinggi.

\section{Peningkatan pengetahuan dan keterampilan siswa bidang elektronika.}

Untuk mengukur berhasil atau tidaknya program pengabdian masyarakat yang telah dilaksanakan, maka perlu dianalisa mulai dari awal pelatihan sampai akhir pelaksanaan pelatihan. Skala yang digunakan untuk mengukur kemampuan peserta adalah range 1-5 (1= buruk sekali, 2 = buruk, 3 = cukup, $4=$ baik dan 5 = baik sekali). Berikut adalah hasil pre-test dan post-test pelaksanaan pelatihan robotika. Tabel 4 menunjukkan hasil pre-test sedangkan Tabel 5 menunjukkan hasil posttest.

Tabel 4. Hasil pre test

\begin{tabular}{lccccc}
\hline \multicolumn{1}{c}{ Materi Umum } & \multicolumn{5}{c}{ Skala } \\
& $\mathbf{1}$ & $\mathbf{2}$ & $\mathbf{3}$ & $\mathbf{4}$ & $\mathbf{5}$ \\
\hline Dasar Komputer & & 20 & 10 & \\
Dasar Elektronika & & 25 & 5 & \\
Dasar Mikrokontroller & & 25 & 5 & \\
Perakitan & 12 & 13 & 5 & \\
Pemprograman & 10 & 18 & 2 & \\
Trouble Shooting & 20 & 10 & & \\
\hline
\end{tabular}


Secara umum kemampuan peserta belum mampu memahami dan menguasai bidang robotika.

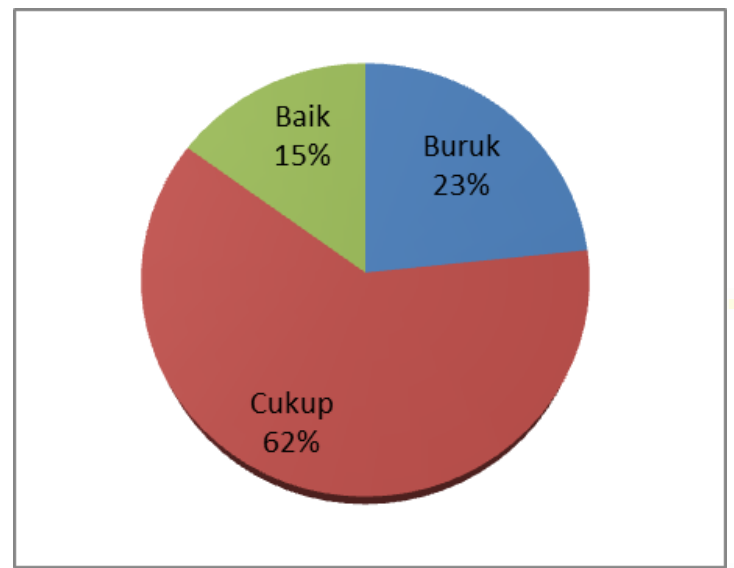

Grafik 1. Rata-rata hasil pretest terhadap kemampuan peserta

Rata-rata hasil pre-test kemampuan peserta tentang elektronika, programming, perakitan robot masih sangat rendah, $23 \%=$ buruk, $62 \%=$ cukup dan $15 \%=$ baik.

Setelah proses pelatihan selama 2 hari berjalan tim pelaksana pengabdian kepada masyarakat melakukan post-test terhadap materi yang sama dan hasilnya dapat dilihat pada Tabel 5.

Tabel 5. Hasil post-test

\begin{tabular}{lcccc}
\hline \multicolumn{1}{c}{ Materi Umum } & \multicolumn{3}{c}{ Skala } \\
& $\mathbf{2}$ & $\mathbf{3}$ & $\mathbf{4}$ & $\mathbf{5}$ \\
\hline Dasar Komputer & & & 15 & 15 \\
Dasar Elektronika & & 16 & 14 \\
Dasar Mikrokontroller & & 10 & 20 \\
Perakitan & 5 & 15 & 10 \\
Pemprograman & 13 & 12 & 5 \\
Trouble Shooting & 5 & 20 & 5 \\
\hline
\end{tabular}

Secara umum kemampuan peserta sudah mampu memahami dan menguasai bidang robotika yang telah diajari selama 2 hari atau setara 14 jam.

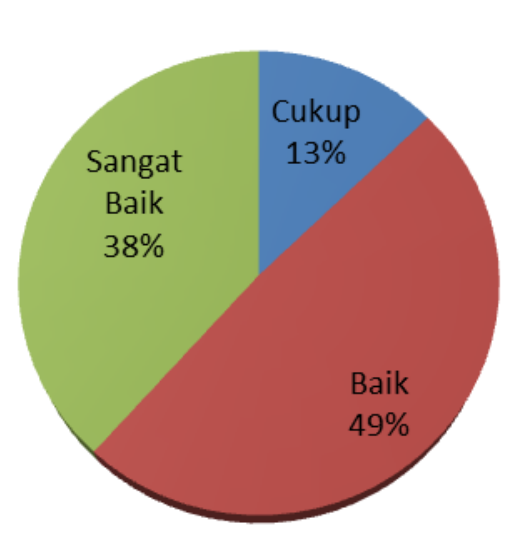

Grafik 2. Rata-rata hasil post test terhadap kemampuan peserta

Rata-rata hasil post-test kemampuan peserta tentang elektronika, programming, perakitan robot mengalami kemajuan yang sangat pesat dengan rincian sebagai berikut: $13 \%=$ Cukup, $49 \%=$ Baik dan $38 \%=$ Sangat Baik.

\section{Terciptanya produk elektronika terapan khususnya robot cerdas pengikut garis dan pemindah barang.}

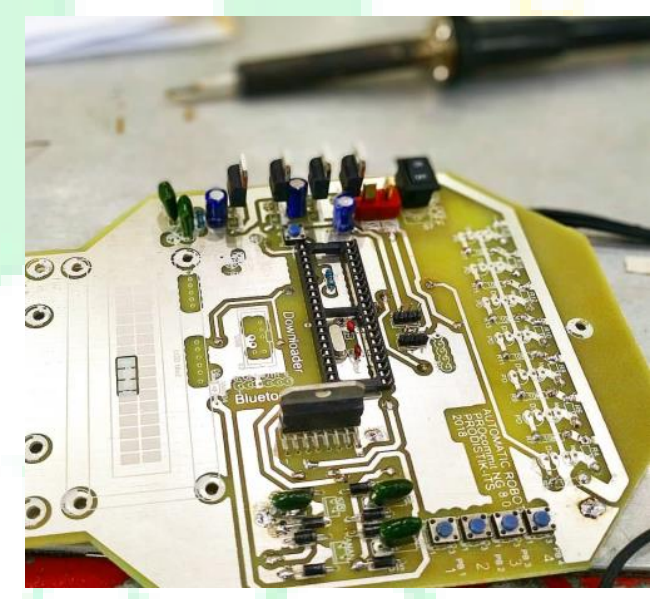

Gambar 4. Hasil pemasangan komponen

Gambar 4 memperlihatkan hasil proses pemasangan komponen oleh peserta kedalam PCB yang telah disiapkan oleh panitia, proses pemasangan komponen dimulai dari sensor dan led, selanjutnya 
proses pemasangan komponen resisitor, kapasitor dan komponen lainnya.

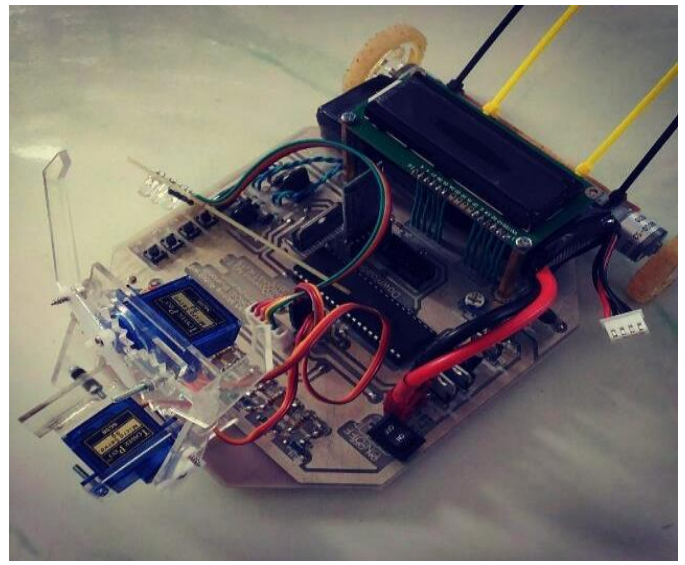

Gambar 5. Hasil perakitan jadi

Gamber 5. Menjelaskan hasil akhir proses pemasangan komponen yang ditambah pelatan pendukung seperti roda, sensor barang, seven segmen dan batre sehingga hasil perakitan secara keseluruhan kelihatan sempurna seperti robot mobil.

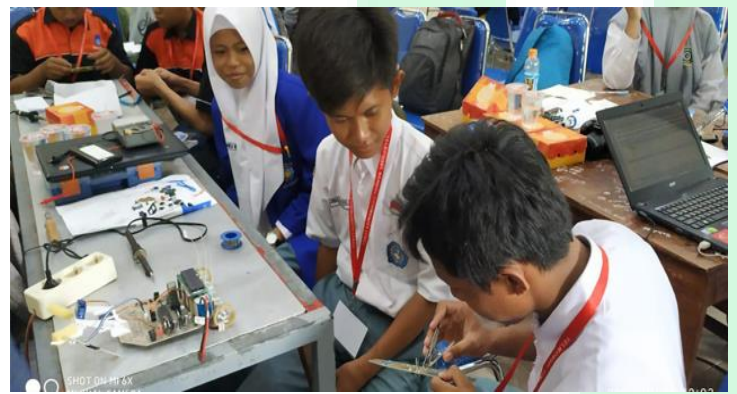

Gambar 6. Proses perakitan siswa

Gambar 6. Menjelaskan proses perakitan hardware robot sudah selesai, selanjutnya adalah menerjemah permasalahan kedalam coding program untuk diinputkan kedalam otak robot (mikrokontroller), tahapan coding sangat diperlukan kerjasama tim untuk saling memberikan pendapat terhadap logika yang akan digunakan.

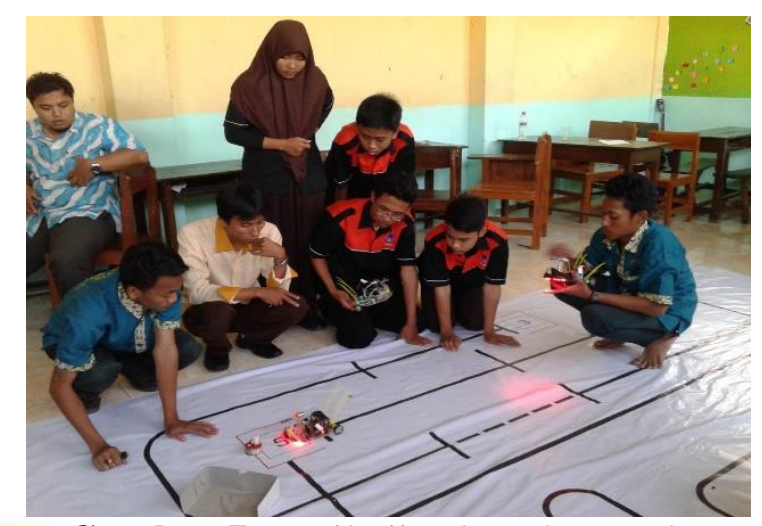

Gambar 7. Hasil uji coba robot cerdas

Gambar 7. Menjelaskan proses uji coba robot yang sudah dirakit dan diisi coding sesuai dengan tantangan yang telah disiapkan oleh panitia. Rata-rata hasil tahapan proses tersebut menyisakan trouble pada masing-masing robot peserta karena banyak peserta yang belum memiliki pengalaman dan ada materi yang terlewati sehingga mereka mengalami kesulitan untuk proses finising membangun robot cerdas sesuai dengan perintah pelatih. Secara detail tahapan proses perakitan dan pemberian coding sudah berjalan dengan baik karena $75 \%$ peserta telah mampu menuntaskan proyeknya.

\section{Peluang wirausaha bidang elektronika.}

Dampak jangka panjang dari program pelatihan ini adalah menumbuhkan wirausaha baru bidang elektronika, bagi peserta yang mau dan menekuni bidang elektronika khususnya robotika.

Sebagai tindak lanjut keberlanjutan program pengabdian kepada masyarakat ini, yang harus dilakukan oleh pihak perguruan tinggi adalah pembinaan dan pendampingan 
pasca pelatihan yang dilakukan. Kampus UIM Pamekasan dan POLTERA harus menjadikan sekolah yang terpilih tersebut menjadi sekolah mitra/binaan yang menjadi prioritas pelaksanaan kegiatan pemberdayaan masyarakat.

\section{KESIMPULAN}

Program pengabdian kepada masyarakat yang dilakukan oleh Universitas Islam Madura dan Politeknik Negeri Madura telah mampu memberikan beberapa outcome, antara lain: peningkatan pengetahuan dan keterampilan siswa SMA/MA bidang sains dan teknologi khususnya bidang robotika, terciptanya sinergi antara perguruan tinggi dengan beberapa sekolah SMA/MA. Program ini juga memberikan impact jangka panjang untuk memotivasi para siswa SMA/MA menekuni bidang usaha dibidang elektronika.

\section{REFERENSI}

Adriyani, W. D. (2017). Pemberdayaan Remaja Putus Sekolah Melalui Pelatihan Keterampilan Tata Rias Dalam Upaya Mendorong Kemandirian Remaja Binaan di Balai Perlindungan dan Rehabilitasi Sosial Remaja Yogyakarta.

Anitasari, L., Bisnis, P. M., Manajemen, P. S., Petra, U. K., \& Siwalankerto, J. (2017). Analisis Pelatihan Sumber Daya Manusia Pada PT. Restu Baru
Indonesia. AGORA, 5(1), 1-5.

Asri, Y. N. (2018). Pembelajaran berbasis stem melalui pelatihan robotika. Jurnal Wahana Pendidikan Fisika, 3(2), 74-78.

Erni Setiyorini, Ning Arti Wulandari, Y. K. S. (2018). Upaya Untuk Meningkatkan Kualitas Hidup Lansia Melalui Perlahat (Persatuan Lansia Ingin Hidup Sehat) di Desa Jatidowo Kecamatan Rejotangan Kabupaten Tulungagung. Community Development Journal, 2(2), 354-366.

Gardening, T., \& Activity, E. (2017). Pengembangan Life Skill Siswa Madrasah Melalui Kegiatan Ekstrakurikuler Berkebun. Adri Efferi, 12(1), 189-212.

Masruroh, Z. (2017). Manajemen pendidikan keterampilan (vocational skill) di man kembangsawit. Muslim Herritage, 1(2), 417-438.

Mirza, A., \& Indah, E. (2015). Pemberdayaan Siswa SMK Melalui Pelatihan Keterampilan Dengan Pemanfaatan Kain Perca Sebagai Peluang Usaha. SOSIO-EKONS, 7(3), 210-215.

Noor, A. H. (2015). Pendidikan Kecakapan Hidup (Life Skill) di Pondok Pesantren Dalam Meningkatkan Kemandirian Santri. Empowerment, 3(2252), 1-31.

Wijaya, W., Bisnis, P. M., Manajemen, P. S., Petra, U. K., \& Siwalankerto, J. (2013). Analisis Pelatihan dan Pengembangan Sumber Daya Manusia Pada Pabrik Kecap Wie Sin di Lombok. AGORA, 1(3), 1-8. 